Body-Size Variation and Fitness Components in Lesser Snow Geese (Chen caerulescens caerulescens)

Author(s): J. Chris Davies, R. F. Rockwell, Fred Cooke

Reviewed work(s):

Source: The Auk, Vol. 105, No. 4 (Oct., 1988), pp. 639-648

Published by: University of California Press on behalf of the American Ornithologists' Union

Stable URL: http://www.jstor.org/stable/4087376

Accessed: 09/04/2012 17:12

Your use of the JSTOR archive indicates your acceptance of the Terms \& Conditions of Use, available at http://www.jstor.org/page/info/about/policies/terms.jsp

JSTOR is a not-for-profit service that helps scholars, researchers, and students discover, use, and build upon a wide range of content in a trusted digital archive. We use information technology and tools to increase productivity and facilitate new forms of scholarship. For more information about JSTOR, please contact support@jstor.org. 


\title{
BODY-SIZE VARIATION AND FITNESS COMPONENTS IN LESSER SNOW GEESE (CHEN CAERULESCENS CAERULESCENS)
}

\author{
J. CHRIS DAVIES,,$^{1,3}$ R. F. ROCKWELL, ${ }^{2}$ AND FRED COOKE ${ }^{1}$ \\ 'Department of Biology, Queen's University, Kingston, Ontario K7L 3N6, Canada, and \\ ${ }^{2}$ Department of Biology, City College of New York, New York 10031 USA, and \\ Department of Ornithology, American Museum of Natural History, \\ Central Park West at 79th Street, New York, New York 10024 USA
}

\begin{abstract}
We examined the potential action of selection on body size in a population of Lesser Snow Geese (Chen caerulescens caerulescens) breeding in the Canadian subarctic. We evaluated the genetic basis of phenotypic variation in body size and examined the association of body size and components of fitness related to fecundity and viability. There was a heritable component to body size in this population derived in part from the action of additive genes. There was no relation between adult body size and the number of eggs laid, the number of eggs surviving predation, the number of goslings that left the nest, or the number of goslings fledged. Small birds entered the breeding population at a younger age. They did so with no reduction in viability and may actually live longer than large birds. The heritable variation in body size combined with the directional selection gradient should lead to a gradual reduction in adult body size in this population. We found no evidence for such a change over 5 generations. We discuss this in terms of additional fitness components, the retarding effects of age structure on the response to selection, and the interaction of selection and gene flow. Received 6 October 1987, accepted 8 May 1988.
\end{abstract}

NATURAL selection acts on phenotypic variation. If that variation has no genetic component, there will be no lasting evolutionary effect (Mayr 1963, Lewontin 1974, Arnold and Wade 1984, Endler 1986; but, see also CavalliSforza and Feldman 1981). This has led evolutionary biologists to study traits that have measurable phenotypic variation, a genetic component of that variation, and some influence on one or more fitness components. Many traits (e.g. body size and plumage coloration) are not direct estimates of fitness but covary with various components of fitness (Arnold and Wade 1984, Endler 1986). For these traits, it is important that all fitness components be considered because the relationship between a given trait and different fitness components may not be of the same magnitude or direction. An increase in body size, for example, could positively affect fecundity but negatively affect survival (Prout 1971).

\footnotetext{
${ }^{3}$ Present address: Ontario Ministry of Natural Resources, Box 190, Moosonee, Ontario POL 1Y0, Canada.
}

Body size has measurable phenotypic variation (Darwin 1859, Bumpus 1899, Semler 1971, Whitney and Krebs 1975, Trivers 1976, Davies and Halliday 1977, Wilbur et al. 1978, Birkhead and Clarkson 1980, Ryan 1980, Arak 1983, Petrie 1983, Verrell 1983). In wild bird populations, that variation can have a genetic component (Boag and Grant 1978, Smith and Zach 1979, van Noordwijk et al. 1980, Boag 1983). Avian body size can influence a number of fitness components. Boag and Grant (1981) found that large adult Darwin's finches (e.g. Geospiza fortis) have high survival during periods of prolonged drought. This high survival of large adult Darwin's finches may be balanced by a high survival rate of small juveniles (Price and Grant 1984). Petrie (1983) found that small fat male and large female Common Moorhens (Gallinula chloropus) had the highest fecundity in her study population. Lessells (1982) found a positive correlation between male body size and clutch size in Canada Geese (Branta canadensis). Ankney and MacInnes (1978) presented evidence for a positive relationship between female body size and fecundity in Lesser Snow Geese (Chen caerulescens caerulescens). 


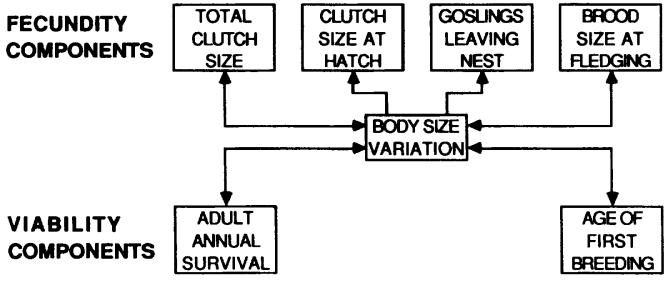

Fig. 1. Fitness components measured in body-size study of Lesser Snow Geese.

Unfortunately, while body-size variation of birds has a genetic basis and while body size may influence individual fitness, most studies have been unable to evaluate both issues. Some have dealt only with the genetic component (Smith and Zach 1979, van Noordwijk et al. 1980, Dhondt 1982, Moss and Watson 1982); others have addressed only potential fitness effects (Fretwell 1969, Jehl 1970, Johnston et al. 1972, Ankney and MacInnes 1978, Petrie 1983). Unless both are considered, it is not possible to evaluate the evolutionary consequences of selection (Endler 1986). We examined both genetic variation and fitness associated with adult body size in a wild population of Lesser Snow Geese.

\section{METHODS}

Study species. - The Lesser Snow Goose is a dichromatic subspecies that nests throughout arctic North America. The La Perouse Bay colony is located $40 \mathrm{~km}$ east of Churchill, Manitoba $\left(58^{\circ} 4^{\prime} \mathrm{N}, 94^{\circ} 4^{\prime} \mathrm{W}\right)$. It is part of the Foxe Basin/Hudson Bay population that shares a migration route down the Mississippi valley and wintering area along the Texas and Louisiana coast (Dzubin et al. 1973). Lesser Snow Geese are monogamous for life. Pairing occurs on the wintering area or during spring migration, and females return (with their mates) to their natal colony to breed. Because La Perouse Bay is a relatively small colony, the vast majority of breeding males at La Perouse Bay come from other colonies, resulting in substantial gene flow into La Perouse Bay (Cooke et al. 1975, Rockwell and Cooke 1977). Geese arrive at La Perouse Bay at the start of spring thaw and nest as soon as sites are available (Abraham 1980a). Clutch size ranges from 1-7 eggs, averaging approximately 4 (Rockwell et al. 1987). Nests were monitored from egg laying to hatching and each gosling received a uniquely numbered web tag allowing individuals to be matched with nests and parents.

Approximately 4 weeks after the hatching period, we captured and banded up to 6,000 goslings and adults. This was just prior to fledging of the goslings and during the adult remigial molt. Because the majority of nonbreeding adults, prebreeders, and nestfailed birds are thought to leave the colony in late June and migrate north to molt (Abraham 1980b), most birds captured each year are successful breeders and their goslings. All unbanded adults and female goslings received a wildlife service band and an alphanumeric color band allowing the birds to be identified individually. About one-fifth of all birds captured each year were previously captured and banded at La Perouse Bay. Every recaptured bird from 1978 to 1981 had bands, sex and plumage color recorded and was also weighed and measured.

We could not identify family groups in the large flocks captured at banding. We identified pairs from observations of individually marked birds either at the nest or on the post-hatch feeding areas. Offspring were measured when they returned to breed at La Perouse Bay.

Body size. -We measured 4 characters on each recaptured bird: (1) Mass-birds were weighed to the nearest $10 \mathrm{~g}$ on a spring scale (cap. $6,000 \mathrm{~g}$ ) which was checked periodically against a known mass; (2) Culmen-we measured the culmen from the tip of the bill to the start of the feather tract on the forehead even if feathers were missing; (3) Head length (head)we measured the distance from the tip of the bill to the top of the occipital process on the back of the head; and (4) Tarsus length (tarsus) - the leg was flexed at the bottom of the crus and at the top of the web. Tarsus is the total length from the bottom of the crus to the web. Culmen, head, and tarsus were measured to the nearest $0.1 \mathrm{~mm}$ with vernier calipers.

We used Principal Component Analysis to combine these measurements and extract a single derived variable, the first principal component (PC1). For highly correlated variables, $\mathrm{PC} 1$ usually explains most of the variance and is commonly used as an index of overall body size (Jolicoeur and Mosimann 1960, Schnell 1970, Johnston et al. 1972, Baker 1975, Gibson et al. 1976, Ricklefs and Travis 1980, Boag 1983). Manly (1986) provides a particularly lucid discussion. At La Perouse Bay, PC1 accounted for $68 \%$ of the total variance of the 4 separate measurements. The measurements contributed positively and equally to $\mathrm{PC} 1$ with specific loadings of mass $(0.84)$, culmen $(0.80)$, head $(0.88)$ and tarsus (0.78).

Fitness components. - We evaluated the fitness of various body-size classes with a general compartment model (Cooke et al. 1985, Rockwell et al. 1987). The model corresponds to the life cycle of the Lesser Snow Goose and successive life stages are used to estimate the fitness components (Fig. 1). We examined the 4 annual fecundity components defined in Cooke et al. (1985): (1) Total clutch laid (TCL) - the total number of eggs laid in a nest. It was only available for those nests found at the 1-egg stage, checked daily during laying, and monitored through to hatch. (2) Clutch 
TABLE 1. Intrapair correlations for 5 indicators of body size for adult Lesser Snow Geese at La Perouse Bay.

\begin{tabular}{lccc}
\hline \hline & $r$ & $P$ & $n$ \\
\hline Mass & 0.24 & $<0.001$ & 436 \\
Culmen & 0.11 & 0.01 & 436 \\
Head & 0.20 & $<0.001$ & 307 \\
Tarsus & 0.12 & 0.02 & 311 \\
PC1 & 0.26 & $<0.001$ & 307 \\
\hline
\end{tabular}

size at hatch $(\mathrm{CSH})$ - the number of eggs in a nest when at least $1 \mathrm{egg}$ had reached the hatching stage. This value was less than or equal to TCL with loss due to partial depredation of the clutch. (3) Goslings leaving nest (GLN) - the number of goslings known to have left the nest after hatch. This value was less than or equal to $\mathrm{CSH}$, with losses due to infertile or rotten eggs, and abandoned eggs or goslings. (4) Brood size at fledging (BSF)-the number of web-tagged goslings that survived to banding from broods in which all members were web-tagged. To reduce the confounding influence of post-hatch fostering, BSF was recorded only if at least 1 banded parent was captured in the same banding drive as the tagged gosling(s).

The viability components of this species were described by Rockwell et al. (1985). We used 2 of the 4 they identified, "the age of first breeding" and "adult annual survival." The data were collected on adult breeding birds and could not be used to evaluate the influence of body size on viability prior to breeding age.

\section{RESULTS}

Heritability.-Estimation of heritability from resemblance between relatives assumes, among other things, that mating is random. The effect of violating this assumption varies with the estimation procedure (Bulmer 1980, Falconer 1981). Nonrandom mating has little effect on heritability values estimated from the regression of offspring on parental means (mid-parent values). Heritability estimates based on single parent-offspring regressions are more seriously affected by nonrandom mating. Positive assortment inflates the estimates and negative assortment reduces them (Bulmer 1980). To correct for any such bias, we estimated the phenotypic correlation between mating pairs for all 5 indicators of size. While all measures were not collected for each pair, the results (Table 1) were consistent for the 5 indicators. In each case, there was a weak but significantly positive correlation between members of a pair.

A total of 96 female offspring, for which the size of at least 1 parent was known, were measured as adults between 1978 and 1981. We assumed that the sample was not biased by under- or overrepresentation of any type of parent-daughter pair, size-specific mortality within families, and size-specific loss of parents. Heritability was estimated from mother-daughter, father-daughter and mid-parent-daughter pairs with standard regression procedures (Bulmer 1980, Falconer 1981; Table 2). Single parent-offspring regression estimates were corrected for assortative mating using correlation coefficients (Table 1). To our knowledge, this is the first example of a wild population where correction for nonrandom mating has been possible. The standard errors of the single parentoffspring heritabilities were twice the errors of their respective regression coefficients. There were no significant differences between the three heritabilities calculated for each of the 5

TABLE 2. Heritability $\left(h^{2}\right)$ estimates for 5 indicators of body-size variation in Lesser Snow Geese at La Perouse Bay, Manitoba. All values are shown with \pm 1 SE. The sample sizes are in parentheses.

\begin{tabular}{lccrc}
\hline \hline $\begin{array}{l}\text { Body-size } \\
\text { measure- } \\
\text { ment }\end{array}$ & $\begin{array}{c}\text { Mother- } \\
\text { daughter }\end{array}$ & Father-daughter $^{\mathrm{a}}$ & Mid-parent-daughter $^{\mathrm{b}}$ & $\bar{x}^{\mathrm{c}}$ \\
\hline Mass & $0.27^{*} \pm 0.12(92)$ & $0.94^{*} \pm 0.28(46)$ & $0.73^{*} \pm 0.20(42)$ & 0.58 \\
Culmen & $0.46^{*} \pm 0.11(92)$ & $0.20 \pm 0.23(46)$ & $0.23 \pm 0.18(42)$ & 0.36 \\
Head length & $0.38 \pm 0.23(52)$ & $0.38 \pm 0.29(17)$ & $0.40 \pm 0.33(16)$ & 0.35 \\
Tarsus & $0.62^{*} \pm 0.29(54)$ & $0.53 \pm 0.21(17)$ & $0.42^{*} \pm 0.17(16)$ & 0.68 \\
PC1 & $0.48^{*} \pm 0.17(52)$ & $0.38 \pm 0.29(17)$ & $0.40 \pm 0.22(16)$ & 0.44 \\
\hline
\end{tabular}

- $h^{2}=\frac{2 \mathrm{x}}{1+\mathrm{y}}$, where $\mathrm{x}=$ regression coefficient, and $\mathrm{y}=$ correlation between parents (Table 1 )

$\mathrm{b} h^{2}=2 \mathrm{x}$

c These are sample-size weighted means of the preceding 3 estimates

* Estimate differs from 0 at $P<0.05$. The $\bar{x}$ values were not tested. 

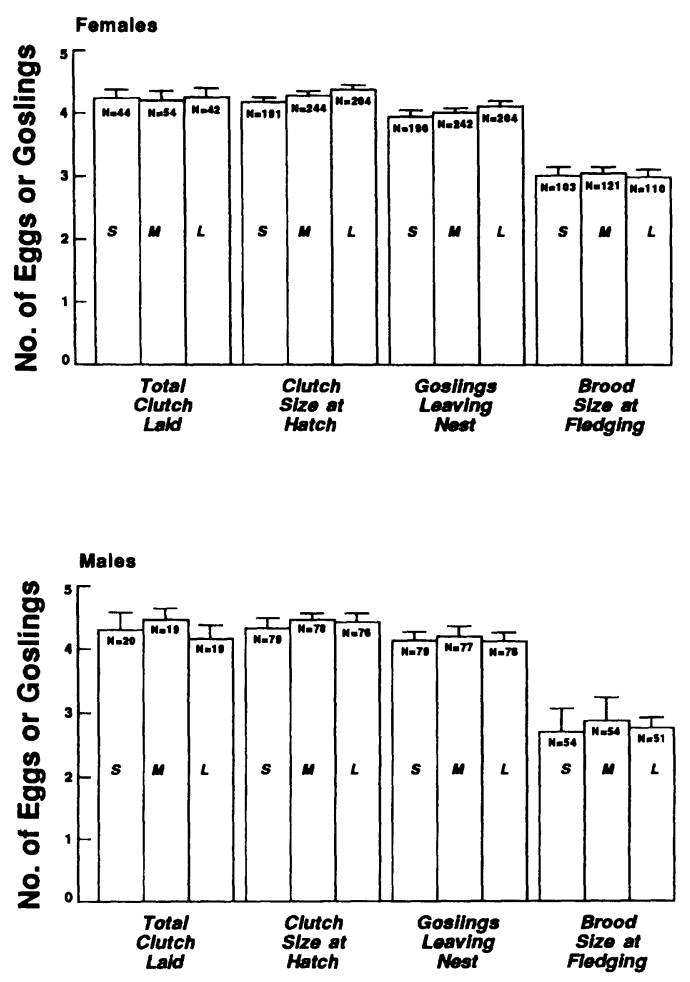

Fig. 2. Distribution of the 4 fecundity variables for different size categories of breeding female and male Lesser Snow Geese. Sample sizes and 1 SE are indicated.

body-size indicators and weighted averages are presented.

Fitness measures (fecundity). - Males and females were each divided into 3 size classes. Medium birds were within half a SD of the mean, large birds were above this, and small birds were below. With this procedure, the 3 classes had equal sample sizes. Data were limited to nests where the female was at least 4 years old to remove age effects on clutch size (Finney and Cooke 1978, Rockwell et al. 1983). Data were pooled over years due to small sample sizes. The relationships between size and the 4 fecundity components are depicted in Fig. 2. We detected no significant differences among the size classes for any of the components.

Cooke and Davies (1983) presented preliminary results suggesting that certain types of pairs (e.g. large male with large female) had higher fecundity. We repeated those analyses with a much larger sample (Fig. 3) but found no significant effect of pair type on the fecundity components. The difference between the 2 studies likely reflects the increased sample size now available.

Fitness components (viability).-Data are from adult birds that returned to the La Perouse Bay colony to breed. These birds were captured and marked individually as goslings, and also were recaptured and measured as adults. Both steps have a low probability and the sample sizes were limited. Older age classes were pooled to maintain adequate sample size. The lack of male natal philopatry restricted the analyses to females.

The average size of females breeding at La Percuse Bay increased up to the age of 4 , and then did not change (Fig. 4). For birds measured more than once, we used only one randomly selected set of measurements in this analysis. There are 3 potential explanations for the shape of this curve: first, incomplete growth with breeding birds continuing to grow to the age of 4; second, size-specific, age-dependent mortality such that small females have a higher mortality than large females at the ages of 2 and 3; finally, differential age of first breeding with small birds starting to breed at an earlier age.

We investigated incomplete growth with a subsample of birds captured once as two-yearolds and again when older. If females continued to grow until age 4, their size would increase between captures. We evaluated this with a paired $t$-test but found no significant difference in size $(t=0.90, n=45)$. Birds did not change in size after first breeding as two-year-olds.

To examine differential size dependent mortality, we sorted each female age class into our 3 size categories. Females were also classified as to whether they returned to La Perouse Bay the following breeding season. The complete set of measured females was used and some birds occur more than once in the analysis. The analysis assumes that the probability that a female is seen, given she returned and bred $1 \mathrm{yr}$ later, is independent of body size, and that the frequency of return was related to differential mortality rather than factors such as breeding propensity.

The data (Table 3) were evaluated for the influence of size and age on female return with Multidimensional Contingency Analysis (MDCA). Return rate depended on unique combinations of age and size as indicated by the significant 3-factor term in the MDCA (Table 4). We evaluated the nature of this interaction by examining the dependency of return rate on 

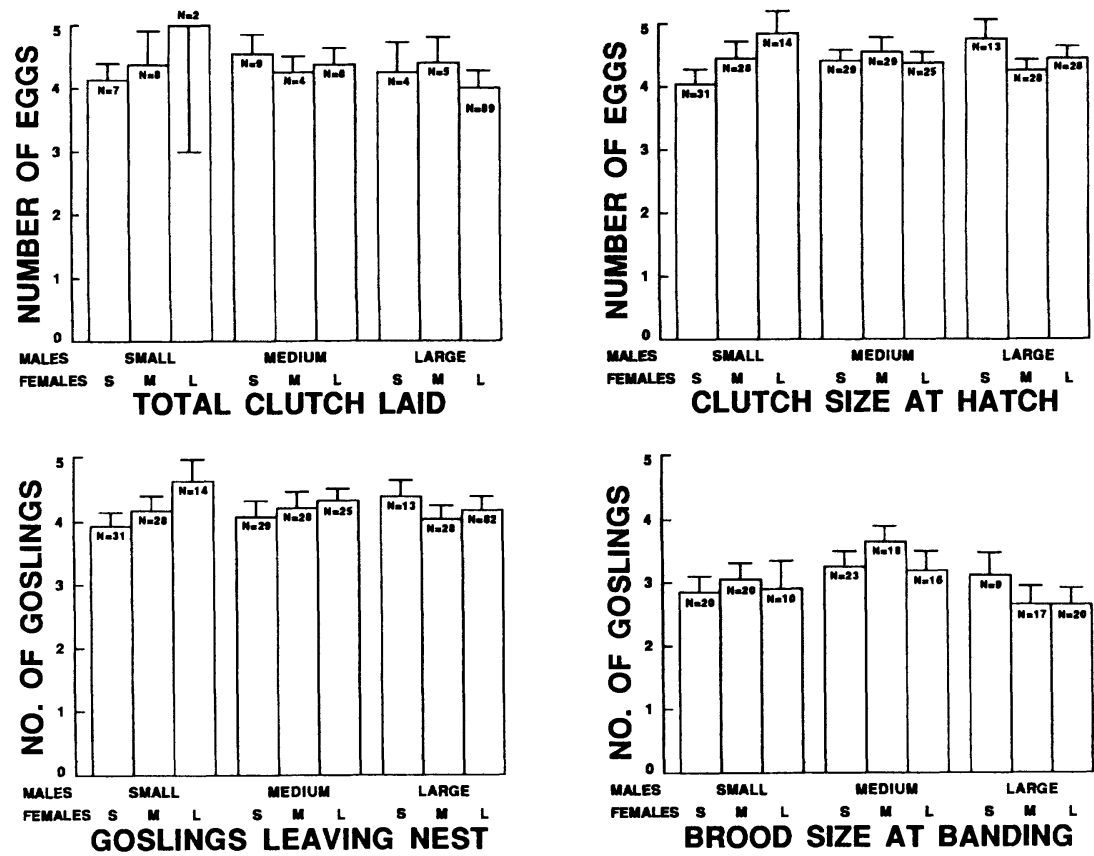

Fig. 3. Distribution of the 4 fecundity components for different pair-size categories of Lesser Snow Geese. Sample sizes and $1 \mathrm{SE}$ are indicated.

size for each age group (Rockwell et al. 1987). Size had no effect on the rate of female return for age classes 2-6. In the oldest age class, comprised of individuals 7 and older, there was a significant effect of size on return rate (log ratio

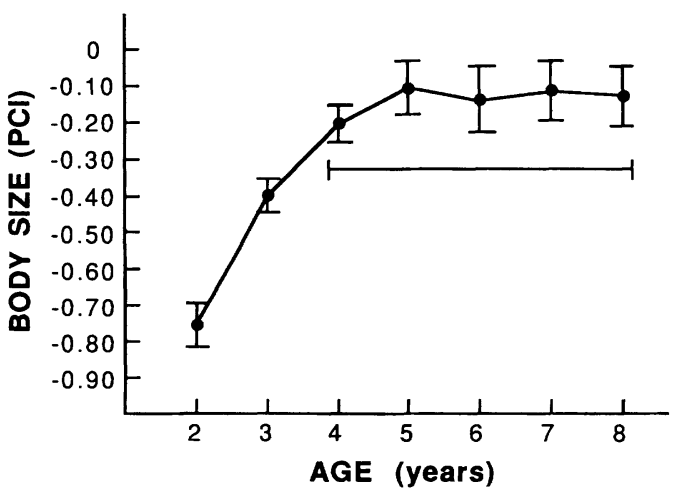

Fig. 4. The relationship between mean female body size, estimated by PC1, and age for Lesser Snow Geese breeding at La Perouse Bay. Error bars indicate $\pm 1 \mathrm{SE}$. The horizontal spans a set of age classes that do not differ significantly from each other (Scheffe's multiple range test). PC1 values below 0 reflect that females are smaller on average than males. Sample sizes for the 7 age classes were, respectively: 232, 205, $160,121,89,69$, and 96 . $\left.\chi^{2}=15.31, \mathrm{df}=2, P<0.001\right)$. For these older females, this resulted from an excess of small females and a paucity of large females that returned to the colony to breed. Overall, this analysis indicated that the increase in average female size through age 4 was not the result of higher mortality of small birds. In fact, there was evidence that small birds live longer.

There was a significant influence of age on the distribution of small, medium, and large birds in each of the age classes $\left(\log\right.$ ratio $\chi^{2}=$ $86.42 ; \mathrm{df}=12 ; P<0.0001$ ). The first 2 age classes were composed predominantly of small and medium-sized birds (Fig. 5). We have shown above that the increase in average size was not due to either growth or size dependent mortality. It is, therefore, most likely that the increase in average size (Fig. 4) resulted from small birds starting to breed at an earlier age than large birds.

\section{Discussion}

A proportion of the phenotypic variation in body size of Lesser Snow Geese is due to genotypic differences among members of the population. Our estimates of the proportion are similar to those obtained for populations of oth- 
TABLE 3. Recurrence of female Lesser Snow Geese 1 year after being measured (1978-1981). Individuals were cross-classified by size, age, and return record.

\begin{tabular}{|c|c|c|c|c|c|c|}
\hline \multirow[b]{3}{*}{ Age } & \multicolumn{6}{|c|}{ Female size } \\
\hline & \multicolumn{2}{|c|}{ Small } & \multicolumn{2}{|c|}{ Medium } & \multicolumn{2}{|c|}{ Large } \\
\hline & Seen & $\begin{array}{l}\text { Not } \\
\text { seen }\end{array}$ & Seen & $\begin{array}{l}\text { Not } \\
\text { seen }\end{array}$ & Seen & $\begin{array}{l}\text { Not } \\
\text { seen }\end{array}$ \\
\hline 2 & 43 & 70 & 31 & 33 & 13 & 20 \\
\hline 3 & 21 & 59 & 25 & 60 & 25 & 35 \\
\hline 4 & 13 & 31 & 27 & 52 & 31 & 36 \\
\hline 5 & 7 & 24 & 17 & 38 & 18 & 40 \\
\hline 6 & 6 & 17 & 14 & 20 & 11 & 31 \\
\hline $7+$ & 15 & 23 & 12 & 65 & 6 & 65 \\
\hline
\end{tabular}

er bird species (Brooke 1977, Boag and Grant 1978, Smith and Zach 1979, van Noordwijk et al. 1980, Garnett 1981, Dhondt 1982, Lessells 1982, Moss and Watson 1982, Boag 1983). It is important to realize that non-zero heritabilities do not necessarily demonstrate additive genetic variance and that estimates may not accurately reflect true population parameters (Boag 1987). Heritability estimates can be influenced by several factors which often cannot be controlled or measured in field studies. These include common environment effects, genotype-environment interactions, and assortative mating. We have corrected for assortative mating and can examine the potential impact of the others in this population.

Females hatched at La Perouse Bay return as breeders to their natal nesting and feeding areas within the colony (Abraham 1980a, Cooke and Abraham 1981). Both mothers and daughters may have been hatched, grown, and fledged in the same portion of the colony. Since the majority of growth occurs at the natal colony, with goslings reaching over $80 \%$ of their adult size before migrating south (Davies and Dzubin unpubl. data), the size resemblance of mothers and daughters may reflect a common environment as well as shared genes (Falconer 1981).

To examine the potential bias of such a common environmental effect, we compared the regressions of mothers and daughters to those of fathers and daughters. Pair formation occurs away from the breeding colony and because $\mathrm{La}$ Perouse Bay is small relative to the total wintering population, most breeding males at La Perouse Bay are immigrants (Cooke et al. 1975). As a result, father-daughter regressions cannot be affected by a common environment at La
TABLE 4. Multidimensional Contingency Analysis shows that return rate, as a measure of survival (see Table 3), depends on unique combinations of size and age. The significant term (resight $\times$ size $\times$ age) is a result of small, old females returning at a higher rate than large, old females.

\begin{tabular}{lrrr}
\hline \hline \multicolumn{1}{c}{ Effect } & df & \multicolumn{1}{c}{$\begin{array}{c}\text { Log- } \\
\text { ratio }\end{array}$} & \multicolumn{1}{c}{$P$} \\
\hline Resight $\times$ size & 2 & 0.95 & 0.9913 \\
Resight $\times$ age & 5 & 32.60 & $<0.0001$ \\
Resight $\times$ size $\times$ age & 10 & 27.11 & 0.0025 \\
\hline
\end{tabular}

Perouse Bay. While fathers and daughters could share migration and wintering area, most growth is completed before migration south and the common fall and wintering environments probably have little effect on final body size. The lack of significant differences between the father-daughter and mother-daughter estimates suggests that common environment between mother and daughter at La Perouse Bay is not a major contributor to heritability of body size in this population.

Genotype-environment interactions result when a specific environment has differing effects on a set of genotypes. Davies (1985) showed a significant contribution of cohort to body-size variation in Lesser Snow Geese (Fig. 6). This effect was due mainly to a very large-bodied 1971 cohort. Finney and Cooke (1978) suggested 1971 was an exceptional year for goslings at La Perouse Bay. This and the reduced range of the body-size distribution for the 1971 cohort suggest the action of a threshold-like genotypeenvironment interaction. In parent-offspring regression methods, such interaction may bias the heritability estimate (Bulmer 1980).

We believe that there is a heritable component to body-size variation in this population which is consistent for all 5 indicators of body size. While the absolute values may be contaminated by some estimation artifacts, the concordance across the 3 procedures, particularly given the different ways they should be affected by such artifacts, suggests that a substantial proportion of the estimated heritability reflects the transmission and segregation of genes with additive effects on body size.

Body size has no direct effect on any fecundity components in Lesser Snow Geese at La Perouse Bay. This is contrary to the findings of Ankney and MacInnes (1978) who argued that 


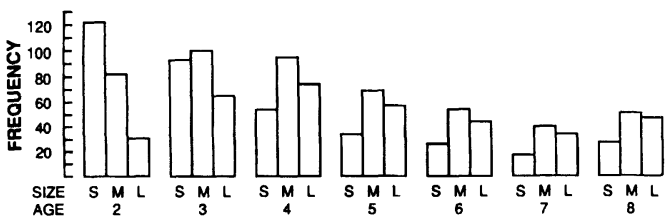

Fig. 5. The frequency distribution of small (S), medium (M), and large (L) females in each of the 7 age categories.

large females laid large clutches. Their conclusion was based on the argument that since female arrival body mass was positively related to both potential clutch size (measured as the number of developing follicles [Ankney 1974]) and body size (measured by culmen), clutch size and body size should also be positively related. Ankney and MacInnes did not examine the relationship between body size and clutch size directly, but inferred it from the other 2 relationships. While such an inference is not necessarily true, our analysis of their raw data (kindly supplied by C. D. MacInnes) shows such a positive correlation.

One explanation for the conflicting results is a difference in age structure in the 2 studies. Ankney and MacInnes worked with an unbanded population of Snow Geese and the age structure of their sample was unknown. Our evidence suggests that small birds breed at an earlier age than large birds. If this were true for the birds collected by Ankney and MacInnes, the small birds in their sample might also have been, on average, young birds. Since young birds lay smaller clutches (Finney and Cooke 1978, Rockwell et al. 1983), the correlation between clutch size and body size found by Ankney and MacInnes could be a result of the younger average age of small birds in their sample.

To examine this, we reevaluated our data. Rather than limiting the fecundity analyses to females aged 4 and older (see above), we included all females, regardless of age. We found significant, but weak, positive correlations between body size (measured as PC1) and all fecundity components (TCL $r=0.21, \mathrm{CSH} r=$ 0.26 , GLN $r=0.24$, BSF $r=0.28$ ). This contrasts with our age-controlled analyses and with correlations using only females aged 4 and greater. It supports the contention that the results of Ankney and MacInnes may reflect the disproportionate inclusion of small, young individuals. We conclude that size per se does not di-

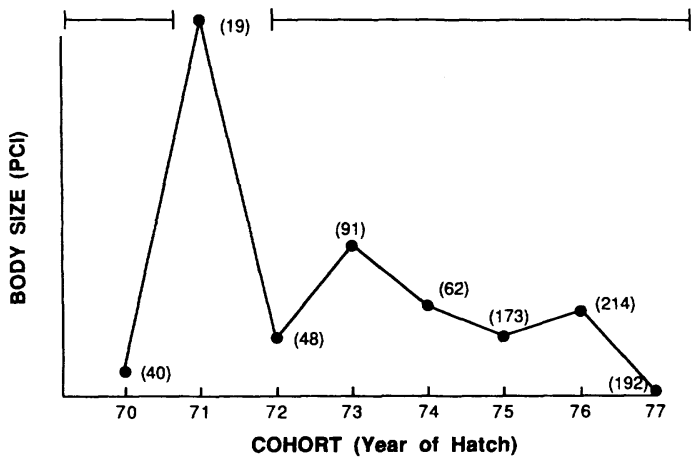

Fig. 6. Female body size for 8 cohorts of Lesser Snow Geese breeding at La Perouse Bay between 1977 and 1982. The horizontal joins cohorts which are not significantly different from each other (Scheffe's multiple range test).

rectly influence annual fecundity in Lesser Snow Geese.

The increased probability of small birds breeding at a younger age can be explained by at least 2 mechanisms. First, there may be some intrinsic advantage associated with small body size that allows small birds to breed earlier than large individuals. Female Lesser Snow Geese rely on stored nutrient reserves for egg laying and incubation and must accumulate these reserves during the spring migration (Ryder 1970, Ankney and MacInnes 1978). Small birds have lower standard metabolic rates and flight costs than large birds (Kendeigh 1972) and require smaller nutrient reserves for existence and migration. If experience is important in allowing Lesser Snow Geese to obtain sufficient nutrient reserves for breeding, as has been shown for Canada Geese (Aldrich and Raveling 1983), small young individuals may be better able to acquire the required amounts.

Second, small birds may be small because they bred as two-year-olds. It is possible that before a female Lesser Snow Goose has completed growth, she switches energy from somatic growth to development of the reproductive system. By doing this, she is able to breed as a twoyear-old but remains a small member of the population. The equivalent and possibly increased survival of small birds is particularly intriguing in view of this mechanism. Unfortunately, distinguishing between these alternatives requires growth curves for individuals from fledging to age of first breeding. These are not easily obtained from a wild population. 
There is a heritable component to body-size variation in Lesser Snow Geese, and there is a fitness differential associated with that variation. Smaller birds have higher fitness than larger ones since they enter the breeding population earlier and may live longer. Under these conditions, we expect a decrease in the average size of female Snow Geese breeding at La Perouse Bay. The average sizes of 8 sequential cohorts are shown in Fig. 6. While there was a significant effect of cohort on body size $(F=$ $2.98, \mathrm{df}=7,531, P<0.01)$, the effect was related solely to the large-bodied 1971 cohort. There was no general decline in the size of breeding females over these 8 consecutive groups of offspring.

There are several explanations for the lack of reduction in average body size. First, all fitness components and their relation to body size must be evaluated to understand fully the evolutionary dynamics of body size in this population. Our data were limited to birds measured as breeding adults and several fitness components could not be evaluated. One, for example, is the relationship between body size and viability during the period from fledging to first breeding. Selection pressures on body size in prebreeders could differ from those affecting breeding adults (Price and Grant 1984).

Second, our analyses were limited to females. Bumpus (1899), Johnston et al. (1972) and Petrie (1983), among others, have shown that selection for body size may differ between sexes. If small body size is favored for females but large size was favored for males, the response to selection in each sex would be retarded.

Third, Lesser Snow Geese are long-lived and populations have overlapping generations. Assuming the selection regime is stable and that the selection intensity is not sufficient to destabilize the age structure, the expected response to selection is reached slowly and asymptotically. This occurs as favored individuals (and alleles) come to dominate the entire age structure (Charlesworth 1980). The mean body sizes of the cohorts (Fig. 6) are measures of the output of an age-structured population which may be slowly accumulating the effects of directional selection for reduced body size. Since the study maximally covers 5 generations (Rockwell et al. 1987), the lack of response so far is perhaps not surprising.

Finally, gene flow into the La Perouse Bay population was $49 \%$, corrected for age structure
(Rockwell and Barrowclough 1987) and reflects male immigration from more northerly colonies. If the greater migration distances or local conditions associated with those colonies impose other selection differentials on body size, then gene flow could swamp any response to local selection on heritable variation in body size of Lesser Snow Geese.

\section{ACKNOWLEDGMENTS}

We thank the many volunteers, field workers, and graduate students who have worked on the La Perouse Bay Snow Goose project. Special thanks go to A. Dzubin and R. Cole who assisted in collection of the body-size measurements. H. Grover, R. Harmsen, D. Hik, R. Jefferies, D. Lank, K. Martin, G. Menard, and $M$. Woolhouse contributed to earlier drafts. The research was supported in part by the Natural Sciences and Engineering Research Council of Canada, the Canadian Wildlife Service, The Wildlife Management Institute, Manitoba Department of Renewable Resources, Central and Mississippi Flyway Councils, Queen's University School of Graduate Studies, the Ontario Graduate Scholarship Program and the American Museum of Natural History. Valuable logistical support in Churchill was provided by the Churchill Northern Studies Centre.

\section{LITERATURE CITED}

ABrahaM, K. F. 1980a. Breeding site selection of the Lesser Snow Goose. Ph.D dissertation, Kingston, Ontario, Queen's University.

. 1980b. Moult migration of Lesser Snow Geese. Wildfowl 31: 89-93.

AldRICH, T. W., \& D. G. RAVELING. 1983. Effects of experience and body weight on incubation behavior of Canada Geese. Auk 100: 670-679.

ANKNEY, C. D. 1974. Importance of nutrient reserves in breeding snow geese. Ph.D. dissertation, London, Ontario, University of Western Ontario.

$\longrightarrow \rightarrow-, \&$ C. D. MACINNES. 1978. Nutrient reserves and reproductive performance of female Lesser Snow Geese. Auk 95: 459-471.

ARAK, A. 1983. Male-male competition and mate choice in anuran amphibians. Pp. 181-210 in Mate choice (P. Bateson, Ed.). Cambridge, Cambridge University Press.

ARNOLD, S. J., \& M. J. WADE. 1984. On the measurement of natural and sexual selection: theory. Evolution 38: 709-719.

BAKER, A. J. 1975. Morphological variation, hybridization and systematics of New Zealand oystercatchers. J. Zool. London 175: 357-390.

BIRKHEAD, T. R., \& K. ClARKSON. 1980. Mate selection and precopulatory guarding in Gammarus pulex. Z. Tierpsychol. 52: 365-380.

BoAG, P. T. 1983. The heritability of external mor- 
phology in Darwin's ground finches (Geospiza) on Isla Daphne Major, Galápagos. Evolution 37: 877-894.

$\longrightarrow \rightarrow 1987$. Effects of nestling diet on growth and adult size in Zebra Finch (Poephila guttata). Auk 104: 155-166.

- \& P. R. GRANT. 1978. Heritability of external morphology in Darwin's finches. Nature 274: 793794.

,$- \&-1981$. Intense natural selection in a population of Darwin's finches (Geospizinae) in the Galápagos. Science 214: 82-85.

BROOKE, M. DE L. 1977. The breeding biology of the Manx Shearwater. Ph.D. dissertation, Oxford, Oxford University.

BULMER, M. G. 1980 . The mathematical theory of quantitative genetics. Oxford, Clarendon Press.

Bumpus, H. C. 1899. The elimination of the unfit as illustrated by the introduced sparrow, Passer domesticus. Pp. 209-226 in Biology lectures, Woods Hole, Marine Biology Laboratory.

Cavalli-Sforza, L. L., \& M. W. Feldman. 1981. Cultural transmission and evolution: a quantitative approach. Princeton, New Jersey, Princeton University Press.

CHARLESWORTH, B. 1980. Evolution in age-structured populations. Cambridge, Cambridge University Press.

COOKE, F., \& K. E. Abraham. 1981. Habitat and locality selection in Lesser Snow Geese: the role of previous experience. Proc. Pp. 998-1004 in 17th Int. Ornithol. Congr. (Berlin).

—, \& J. C. DAvies. 1983. Assortative mating, mate choice and reproductive fitness in Snow Geese. Pp. 279-295 in Mate choice (P. Bateson, Ed.). Cambridge, Cambridge University Press.

- C. S. Findlay, R. F. ROCKWELl, \& J. A. SMITH. 1985. Life history studies of the Lesser Snow Goose (Anser caerulescens caerulescens). III. The selective value of plumage polymorphism: net fecundity. Evolution 39: 165-177.

$-\rightarrow-$ C. D. Macinnes, \& J. P. PrevetT. 1975. Gene flow between populations of Lesser Snow Geese. Auk 92: 493-510.

- \& D. S. SulzbaCh. 1978. Mortality, emigration and separation of mated Snow Geese. J. Wildl. Manage. 42: 271-280.

DARWIN, C. 1859. The origin of species by means of natural selection. London, Murray.

DAvies, J. C. 1985. Body size in adult Lesser Snow Geese: assortative mating, heritability and fitness. Ph.D. dissertation, Kingston, Ontario, Queen's University.

Davies, N. B., \& T. R. Halliday. 1977. Optimal mate selection in the toad, Bufo bufo. Nature 269: 5658.

DHONDT, A. A. 1982. Heritability of Blue Tit tarsus length from normal and cross fostered broods. Evolution 36: 418-419.
Dzubin, A., H. BoYd, \& W. J. D. StEPHEN. 1973. Blue and Snow goose distribution in the Mississippi and Central flyways, 1951-1971. Report prepared for Central and Mississippi Flyways Councils and Technical Committees by the Can. Wildl. Serv.

ENDLER, J. A. 1986. Natural selection in the wild. Princeton, New Jersey, Princeton University Press.

FALCONER, D. S. 1981. Introduction to quantitative genetics. London, Longman Group Ltd.

FINNEY, G. H., \& F. COOKE. 1978. Reproductive habits in the Snow Goose: the effect of female age. Condor 80: 147-158.

FRETWELl, S. D. 1969. Dominance and winter habitat distribution in juncos. Bird Banding 40: 1-25.

GARNETT, M. C. 1981. Body size, its heritability and influence on juvenile survival among Great Tits. Ibis 123: 31-41.

Gibson, A. R., M. A. Gates, \& R. ZaCh. 1976. Phenetic affinities of the Wood Thrush, Hylocichla mustelina. Can. J. Zool. 54: 1679-1687.

JEHL, J. R. 1970. Sexual selection for size differences in two species of sandpiper. Evolution 24: 311319.

Johnston, R. F., D. M. Niles, \& S. A. Rohwer. 1972. Herman Bumpus and natural selection in the House Sparrow, Passer domesticus. Evolution 26: 20-31.

Jolicoeur, P., \& J. E. MosimanN. 1960. Size and shape variation in the painted turtle. A principal component analysis. Growth 24: 239-254.

KENDEIGH, S. C. 1972. Energy control of size limits in birds. Am. Nat. 106: 79-87.

LESSELLS, C. M. 1982. Some causes and consequences of family size in the Canada Goose, Branta canadensis. Ph.D. dissertation, Oxford, England, Oxford University.

LEWONTIN, R. C. 1974. The genetical basis for revolutionary change. New York, Columbia University Press.

MANLY, B. F. J. 1986. Multivariate statistical methods: a primer. London, Chapman and Hall.

MAYR, E. 1963. Animal species and evolution. Boston, Harvard University Press.

Moss, R., \& A. WATSON. 1982. Heritability of egg size, hatch weight, body weight and viability in Red Grouse (Lagopus lagopus scoticus). Auk 99: 683686.

PETRIE, M. 1983. Female Moorhens compete for small fat males. Science 220: 413-415.

Price, T. D., \& P. R. GRANT. 1984. Life history traits and natural selection for small body size in a population of Darwin's finches. Evolution 38: 483494.

Prout, T. 1971. The relationships between fitness components and population prediction in Drosophila. I. The estimation of fitness components. Genetics 68: 127-149.

Ricklefs, R. E., \& J. Travis. 1980. A morphological 
approach to the study of avian community organization. Auk 97: 321-338.

ROCKWELL, R. F., \& G. F. BARROWCLOUGH. 1987. Gene flow and population genetic structure. Pp. 223255 in Avian genetics (F. Cooke and P. Buckley, Eds.). London, Academic Press.

$\longrightarrow$, \& F. COOKE. 1977. Gene flow and local adaptation in a colonially nesting dimorphic bird: the Lesser Snow Goose. Am. Nat. 111: 91-97.

- C. S. FindlaY, \& F. COOKE. 1983. Life history studies of the Lesser Snow Goose. I. The influence of age and time on fecundity. Oecologia (Berl.) 56: 318-322.

$\longrightarrow, \longrightarrow-1987$. Is there an optimal clutch size in Snow Geese? Am. Nat. 130: 839863.

$\longrightarrow,-, \longrightarrow$, J. SMITH. 1985. Life history studies of Lesser Snow Geese (Anser caerulescens caerulescens). IV. The selective value of plumage polymorphism: net viability, the timing of maturation and breeding propensity. Evolution 39: 178-189.

RYAN, M. T. 1980. Female choice in a Neotropical frog. Science 209: 413-415.

RYDER, J. P. 1970. A possible factor in the evolution of clutch size in Ross' goose. Wilson Bull. 82: 513.

SCHNELL, G. P. 1970. A phenetic study of the suborder Lari (Aves) I. Methods and results of principal component analysis. Syst. Zool. 19: 35-37.

SEMLER, D. E. 1971. Some aspects of adaptation in a polymorphism for breeding colours in the Threespined Stickleback (Gasterosteus aculeatus). J. Zool. London 165: 291-302.

SMITH, J. N. M., \& R. ZACH. 1979. Heritability of some morphological characters in a song sparrow population. Evolution 33: 460-467.

TRIVERS, R. L. 1976. Sexual selection and resources accrual in Anolis garmani. Evolution 30: 253-269.

VAN NOORDWIJK, A. J., J. H. VAN BALEN, \& W. SchaRLOO. 1980. Heritability of ecoiogically important traits in the Great Tit. Ardea 68: 193-202.

VerRell, P. A. 1983. Some problems in the study of anuran pairing patterns. Oikos 41: 148-149.

Whitney, C. L., \& J. R. KREBS. 1975. Mate selection in Pacific tree frogs. Nature 255: 325-326.

Wilbur, H. M., D. I. RUBENSTEIN, \& L. FAIRCHILD. 1978. Sexual selection in toads: the role of female choice and male body size. Evolution 32: 264-270.

Wisconsin Project Loon Watch is accepting applications for its fourth annual award for research on Common Loons in the Lake Superior-Lake Michigan region of the United States and Canada. To apply for cash awards up to $\$ 4,000$, a brief description (maximum 10 pages) of the proposed research program and curriculum vitae should be submitted by the principal investigator to Paul I. V. Strong, Coordinator, Wisconsin Project Loon Watch, Sigurd Olson Environmental Institute, Northland College, Ashland, Wisconsin 54806 USA.

Proposals must be received by 6 January 1989. Student proposals should be accompanied by two letters of recommendation. The award will be granted on the basis of the project's contribution to deeper understanding and better management of Common Loon populations of the Upper Great Lakes. Guidelines for applicants are available from WPLW. 